http://economix.fr

Social capital and access to primary health care in developing countries: Evidence from Sub-Saharan Africa

Document de Travail

Working Paper 2015-06
Guillaume Hollard Omar Sene

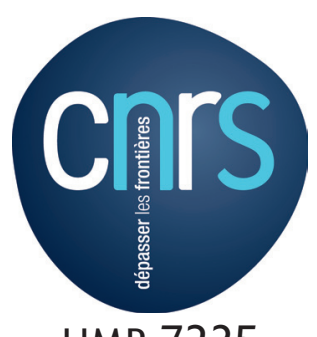

UMR 7235
Université de Paris Ouest Nanterre La Défense (bâtiment G)

200, Avenue de la République 92001 NANTERRE CEDEX université

Paris Ouest

Nanterre La Défense 


\title{
Social capital and access to primary health care in developing countries: Evidence from Sub-Saharan Africa ${ }^{1}$ Guillaume Hollard ${ }^{\mathrm{a}}$ and Omar Sene ${ }^{\mathrm{b}}$ \\ ${ }^{a}$ Ecole Polytechnique and CNRS E-mail: guillaume.hollard@polytechnique.edu. \\ bconomX, University Nanterre Paris-Ouest La Défense, E-mail: omar.sene@u-paris10.fr.
}

\begin{abstract}
We test the causal role of social capital, as measured by self-reported trust, in determining access to basic health facilities in Sub-Saharan Africa. To skirt reverse-causality problems between social capital and basic health, we rely on instrumental variable (IV) estimates. The results show that a one standard deviation increase in the level of localized trust leads to a 0.221 standard deviation decrease in the predicted value of doctor absenteeism, a 0.307 standard deviation decreases in the predicted value of waiting time and a 0.301 standard deviation decreases in the predicted value of bribes. As a robustness check, we also use a different database regarding a different health issue, namely access to clean water. We find that a one standard deviation increase in the level of localized trust leads to a 0.330 standard deviation increase in the access on clean water. All in all, social capital is found to have an important causal effect on health, even stronger that the one found in western countries.
\end{abstract}

Keywords: Social Capital, Health, Africa, Causality.

JEL Classification: I15; I12; D71; I18; H41

\footnotetext{
${ }^{1}$ We thank Yann Algan, Jean-Marie Baland, Margherita Comola, Fred Cooper, Pascaline Dupas, Leontine Goldzahl, Hela Maafi, Lorenzo Rocco, Jason Shogren and Antoine Terracol for useful comments and suggestions.
} 


\section{Introduction}

Starting with China's barefoot doctors in the 1930's, the provision of basic health care at the local level has been an innovative way of improving health in poor areas. The Alma-Ata international conference in 1978 acknowledged the success of local primary health care systems and recommended the generalization of their use across the globe. There is now almost a consensus that health systems concentrating on primary health care produce better outcomes, at lower costs, and with greater user satisfaction.

The importance of local health facilities is reinforced in sub-Saharan Africa, where communities are often faced with limited government resources and need to organize themselves to provide health services to community members. It is no exaggeration to state that basic health services are now in community hands in sub-Saharan Africa. As a result, the ability of communities to engage in collective action (e.g. by maintaining health facilities) and promote the relevant social norms (e.g. introducing sound hygiene practices) would appear to be crucial for health improvements in Africa. This ability is often referred to as social capital. Intuition suggests that communities endowed with more social capital should be better able to provide local health services, all else being equal, suggesting a causal relation between social capital and health. The aim of this paper is to test the relationship between social capital and heath in Sub-Saharan Africa.

The analysis here has profited from previous works in at least three ways. First, research using data from Western countries has found that health and social capital are connected (Rocco et al. 2014, Rocco 2014, D’Hombres et al. 2010 and Islam et al. 2006 for a review). Since no such quantitative work is available for Sub-Saharan Africa, it will also be useful to compare the effect found across continents. Second, we also benefit from a now well-established line of research highlighting the relevance of the notion of social capital for economic analysis (see Algan and Cahuc, 2013 for a recent survey). In particular, there is now growing evidence that despite the lack of a precise definition, a sensible measure of social capital can be obtained through simple survey questions regarding trust. By using the exact same type of question, we are confident that the trust measure we use is a reasonable proxy for the notion of social capital to which we refer (Algan, Y., and Cahuc, P., 2010). Last, thanks to the Afrobarometer initiative, good-quality data for many sub-Saharan countries are now available. This allows us to carry out rigorous tests of our assumption in over 1000 districts across 16 African countries. 
The empirical analysis of the effect of social capital on the quality of community governance poses endogeneity problems: social capital and the quality of local public goods may be mutually reinforcing (Rocco et al, 2014; Rocco, 2014). Individuals endowed with more social capital may indeed participate more in the provision of public goods. But equally those who are more involved in public-good activities may create more social links, have more trust in others and thus have more social capital. If this is the case, the coefficients on social capital in simple health regressions will be biased. We here use an instrumentalvariable (IV) approach to deal with these endogeneity problems. We construct a measure particular to each ethnic group, called "inherited trust", to instrument current trust. To this end, we use data on historically-determined patterns of ethnic land settlement collected by Murdock (1967). We assume that individuals' trust levels are inherited along ethnic lines, in the spirit of Nunn and Wantchekon (2011) who underline the long-lasting impact of the slave trade on contemporaneous trust levels in Africa. Inherited trust can be assumed to affect current trust, but to be uncorrelated with our dependent variable, namely health-care quality. As a result, different levels of inherited trust only affect health via their effect on current trust. This allows us to say how health indicators would react to an exogenous change in current trust, and thus establishes the causal effect of social capital on health.

We find that social capital, as measured by trust, has a causal impact on access to health care in Africa. For instance, a one standard deviation increase in the level of localized trust leads to a 0.221 standard deviation decrease in the predicted value of doctor absenteeism, a 0.307 standard deviation decrease in the predicted value of waiting time and a 0.301 standard deviation decrease in the predicted value of bribes. Using an alternative data set as a robustness check, we also find that a one standard deviation increase in the level of localized trust leads to a 0.330 standard deviation increase in the access on clean water and to 0.080 standard deviation increases in hygienic practices. Our results provide large-scale evidence regarding the claim that social capital plays a causal and important role in access to basic health services in Africa.

The remainder of the paper is organized as follows. Section 2 provides a review of the literature. Section 3 describes data. Our empirical strategy is presented in Section 4 and the results appear in Section 5. Section 6 concludes. 


\section{Literature Review}

Since "Health" and "Social Capital" are quite broad notions, some clarifications and definitions are in order. We first explain how social capital can be measured so as to appear in statistical analyses; we then briefly review the existing evidence on social capital and health. Since to the best of our knowledge there are only a limited number of comparable studies using African data, we describe the main features of the health situation in Africa and suggest the critical role that social capital may play in this respect.

\subsection{Social capital: definitions, effects and measures}

Social capital is a broad notion which is certainly helpful for thinking about what it is that connects individuals within a community. The well-known works of Putnam (2000) and Coleman (1990) discuss social capital in a convincing manner to explain the dynamics of contemporary societies. The use of the term "social capital" has now spread out beyond the world of academia. NGOs and governments, as well as popular discourse, regularly refer to social capital to explain various aspects of social life.

Economists have typically been rather reluctant to appeal to a notion that is so loosely defined and hard to measure (Sobel (2002)). However, the emerging field of cultural economics has been successful in furnishing quantitative evidence that social norms and values do explain some current important economic outcomes. A key finding is that simple trust questions provides a good proxy for social capital. For instance, Uslaner (2008) notes that "trust is a value that leads to many positive outcomes for a society: greater tolerance of minorities, greater levels of volunteering and giving to charity, better functioning government, less corruption, more open markets, and greater economic growth." Therefore, measuring the proteiform notion of social capital using simple trust questions should not be too much of a stretch (Uslaner, 2008; Algan and Cahuc, 2013).

\subsection{Social capital and health}

The effect of social capital can be measured in several ways, follow a number of pathways and affect various health issues. However, despite its multidimensional nature, social capital is found to have a positive effect whatever the measure used (e.g. trust questions or number of friends), the possible pathways followed (e.g. better information or less free riding) and the various health issues considered (e.g. self-reports on health condition, 
diagnostics or mortality rates $)^{2}$. To illustrate this robustness of the relation between social capital and health, we here review a number of studies that vary in their measures used. D'Hombres et al. (2009) find a positive and significant relation between individual selfreported health and various measures of social capital such as trust, participation in local organizations and social isolation. These results are confirmed by Ronconi et al. (2012), who measure social capital by informal interactions in Argentina, and find that both men and women with more social capital report better health. Herian et al. (2014) examine the impact of average interpersonal trust on health at the state level in the U.S. They find that individuals report better health in States with greater social capital. Mental health is also found to be positively associated with various dimensions of social capital. For example, Borgonovi (2010), who considers the extent to which social capital can promote individual well-being in the form of good physical and mental health, finds that individuals with more social capital generally fare better than individuals with less social capital. Carpiano and Fritterer (2014) using Canadian data find that trust is positively associated with mental health. In the same vein, there is some strong evidence that community voluntary organization, another dimension of social capital, is a good determinant of various forms of health. Brown et al. (2006), for example, measure social capital by membership of religious groups and find that community social capital is strongly and negatively related to the number of cigarettes that smokers consume. The same type of association is found by Yoon and Brown (2011) regarding obesity in the US. Nauenberg et al. (2011) use the Petris index to measure social capital and show that more social capital is associated with fewer general practitioner visits, using data from the Ontario Health Ministry. Note that whether social capital plays a similar role in Africa is to a large part an open question.

The empirical analysis of the effect of social capital on the quality of community governance poses, however, endogeneity problems: social capital and the quality of access to health care may mutually reinforce each other (Rocco et al. (2014), Rocco (2014)). Rocco et al. (2014), for example, address this problem of reverse causality by estimating a simultaneous-equations model. Using data from the first four waves of the European Social Survey for 26 European countries, they find a causal and positive relationship between self-

\footnotetext{
${ }^{2}$ Some sociologists such as Cattel (2001), Hawe and Shiell (2000), Kennely et al. (2003) and O’Brien Caughy et al. (2003) have, however, provided evidence on a negative effect that social capital can have in health. O'Brien Caughy et al. (2003), for example, find that in wealthy neighborhoods, children whose parent reported knowing few of the neighbors had higher levels of internalizing problems such as anxiety and depression compared to those who knew many of their neighbors. In contrast, in poor neighborhoods, children whose parent reported knowing few of the neighbors had lower levels of internalizing problems compared to those who knew many of their neighbors.
} 
perceived health and social capital in both directions. These findings are confirmed by Goryakin et al. (2014), who employ instrumental-variable estimation to address this issue of reverse causality in social capital. Their results reveal a causal association running from several dimensions of individual social capital to general and mental health. Similar conclusions are reached by D'Hombres et al. (2010) who consider the impact of social capital on self-reported health for eight countries from the Commonwealth of Independent States using instrumental-variable estimates. Their results confirm that social capital causally affects health.

\subsection{Health in Africa}

Despite very substantial progress, health systems in sub-Saharan Africa are generally considered to be the worst-performing in the world, even when compared to other poor continents like South America or Asia. Both health infrastructures and outcomes are often poor: for instance, only $58 \%$ of people living in sub-Saharan Africa have access to safe water supplies. Of the 20 countries with the highest maternal mortality ratios worldwide, 19 are in Africa. Africa counts for $11 \%$ of the world's population but $60 \%$ of individuals with HIV. These poor outcomes suggest that considerable improvements can be achieved. These improvements are in addition not that costly. For example, Morel et al. (2005) show that the use of insecticide-treated bed nets can reduce the incidence of malaria by 50 percent and mortality by 20 percent. The simple treatment of water to make it safe to drink can reduce endemic diarrhea by $37 \%$. The use of condoms is an efficient way of preventing HIV.

The particularity of Africa, compared to other continents, is that major health improvements are within reach. We may then wonder what prevents these benefits from being realised. A critical review of the determinants of health in Africa is beyond the scope of the present paper (see Dupas (2011) for a stimulating survey). The point we make here is that a substantial portion of these potential improvements can reasonably be linked to social capital. For instance, social capital is likely to facilitate the diffusion of good practices via social networks. There are indeed a number of instances of insufficient information preventing the adoption of sound health practices (Ensor and Cooper (2004), Jyotsna and Somanathan (2008)). Social capital can also operate through the ability of local communities to engage in collective action. It is important to bear in mind that local communities in Africa often face very limited government resources and need to rely on informal networks, facilities run by NGOs or local communities to access health care. Basic health inputs (e.g. whether there exists a building where it is possible to meet a doctor or whether the water is safe to 
drink) are in the hands of local communities. Information and collective action are only two examples of the channels via which social capital may have a considerable impact on health in Africa, but suffice for us to conjecture that the health effect of social capital should be significantly larger in Africa than in Western Europe.

\section{Data and variable definitions}

We use three different databases to test the causal effect of trust on access to basic health care: the Afrobarometer (2005), the Demographic and Health Survey (DHS 2005) and Murdock's Ethnographic Atlas (1967). The Afrobarometer data comes from nationallyrepresentative samples of primary sampling units (PSUs) selected with a probability proportional to population size (with a minimum size of 1200$)^{3}$. We here use data from 16 countries: Benin, Botswana, Ghana, Kenya, Lesotho, Madagascar, Malawi, Mali, Mozambique, Namibia, Nigeria, Senegal, South Africa, Tanzania, Uganda and Zambia. Data are available at the district level, which is the smallest administrative level within a country, and cover more than 1335 districts. The surveys were face-to-face in the respondent's language of choice. The third round of the Afrobarometer collected information on some individual-level indicators of social capital, livelihoods, and the perception of democracy. The descriptive statistics of the socio-economic variables in the sample appear in Table 1. The second database, the DHS is nationally-representative and includes over 300 surveys in more than 90 countries. We use versions V and VI of the DHS across 11 African countries. The data from DHS is matched to that from the Afrobarometer using geographical coordinates: each household surveyed in the DHS is assigned to the Afrobarometer district of which the center is the nearest to its location using the great circle method (the circle formed on the surface of the Earth by a plane passing through the center of the Earth). Information on historical settlement patterns is drawn from the ethnographic Atlas of Murdock (1967), which compiled a great deal of ethnographic work into one database and classified 1.167 societies around the world according to culture and societal institutions. This database contains information on the pre-colonial conditions and characteristics of many ethnic groups and tribes within Africa.

Additional information on the historical emplacement of ethnic groups' homelands and their current locations are drawn from Nunn and Wantchekon (2011), which deals with the impact of the slave trade on trust in Africa.

\footnotetext{
${ }^{3}$ A detailled description of the sampling units and enumeration areas can be found in the afrobarometer's survey manuel (pp 33-34) available at www.afrobarometer.org/survey-and-methods/survey-manuals
} 


\subsection{Social capital}

Two indicators are used to measure social capital: generalized trust and trust in neighbors. The first, generalized trust, is measured using the General Value Survey (GVS) trust question: "Generally speaking, would you say that most people can be trusted, or that you cannot be too careful in dealing with people?" Respondents reply either "Most people can be trusted" or "You must be very careful". The level of trust in the district is given by the percentage of individuals who respond "Most people can be trusted". This trust measure is by far the most common in empirical work, and is often presented as a proxy for social capital. The second indicator is trust in neighbors. The exact question wording is: "How much do you trust each of the following types of people: Your neighbors?" Respondents choose between four possible answers: (i) not at all, (ii) just a little, (iii) somewhat, or (iv) a lot. The distributions of the district levels of trust appear in Figure 1 for generalized trust and Figure 2 for trust in neighbors. As can be seen, the level of trust is very heterogeneous both across districts and between countries. A further look at Figure 1 reveals that generalized trust is very low in Africa: in only few districts do more than half of people agree that "Most people can be trusted". The degree of trust in neighbors, in Figure 2, is somewhat higher since most districts exhibit figures around the mean (which equals 2 here).

\subsection{Indicators of the quality of access to basic health care}

We consider three types of health outcomes. (1) We use data from the Afrobarometer relative to health-center quality. Afrobarometer respondents were asked about the services of local health centers in each district regarding seven dimensions: the clinics being too expensive (EXP), a lack of medicines/supplies (MES), doctor absenteeism (DABS), long waiting times (LWA), dirty facilities (PFA), problems of illegal payments (ILP) and lack of attention/respect (LREP). (2) Using data from the DHS, we construct a composite index of water-treatment behavior (WTI) via principal components analysis. Our index, computed at the household level, captures most of the variance in the efforts made by households to make water safe to drink. (3) Using DHS data, for each district, we compute the variable Prop well corresponding the proportion of people using improved drinking water sources: public standpipe, borehole, protected dug well and protected spring (as opposed to those who drink water from an unprotected source). Descriptive statistics of these indicators appear in Table 1. 


\section{Empirical strategy}

Two types of estimations are carried out: at the district level for the quality of health centers and access to safe drinking water; at the individual level for the water-treatment index.

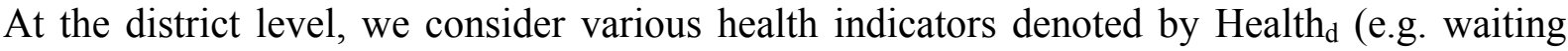
time or lack of medicine).

We estimate the following equation:

$$
\text { Health }_{d}=\pi_{0}+\pi_{1} \text { Trust }_{d}+\pi_{2} \mathrm{Y}_{d}+\text { Ctr. f. e. }+\varepsilon_{d}
$$

The variable Trust $_{d}$ is district-level trust, where the two trust measures, generalized trust (Trust_GVS) and trust in neighbors (Trust_Neigh ), will be considered separately. We control for a certain number of district characteristics $Y_{d}$ (see Table 1 for the descriptive statistics of these controls). We control for country fixed-effects and $\varepsilon_{\mathrm{d}}$ is the error term. $\pi=$ $\left(\pi_{0}, \pi_{1}, \pi_{2}\right)$ are the coefficient of the parameters of interest.

At the household level, we estimate the following equation:

$$
\mathrm{WTI}_{i, d}=\delta_{0}+\delta_{1} \mathrm{X}_{i}+\delta_{2} \mathrm{Y}_{d}+\delta_{3} \text { Trust }_{d}+\text { Ctr.f. e. }+\varepsilon_{i, d}
$$

$\mathrm{WTI}_{\mathrm{i}, \mathrm{d}}$ denotes the behavior of household $\mathrm{i}$ (the water-treatment index), in district $\mathrm{d}$. We control for a certain number of household characteristics $\mathrm{X}_{\mathrm{i}}$ (see Table 1 for the descriptive statistics of these controls). Other variables are the same as described in equation 1 .

If trust is endogenous, OLS estimation will not be consistent: we therefore appeal to instrumental variables. Our IV equation can then be specified as:

$$
\begin{aligned}
& \text { Health }_{d}=\pi_{0}+\pi_{1} \text { Trust }_{d}+\pi_{2} \mathrm{Y}_{d}+\text { Ctr.f. e. }+\varepsilon_{d} \\
& \text { Trust }_{d}=\rho_{0}+\rho_{1} \text { Inherit }_{d}+\rho_{2} \mathrm{Y}_{d}+\text { Ctr.f. e. }+\sigma_{d}
\end{aligned}
$$

where Inherit is inherited trust in the district, used as instrumental variable (see below for details). Other variables are as defined in equations 1 and 2.

\subsection{Instruments}

We are looking for a variable that affects current levels of trust without having a direct effect on health issues. We here consider inherited trust. There is indeed evidence that current trust is rooted in long-term history. For instance, Nunn and Wantchekon (2011) show that slave trade still affects current levels of trust centuries after it took place. They show that this inherited trust is transmitted along the ethnic lines. For instance, let us consider the current level of trust of a member of the Bantu ethnic group. Part of his, or her, current level of trust is inherited from his Bantu ancestors. Now consider that this individual is now living in the 
Fon's territory. Since individuals do move while infrastructures don't, the inherited level of trust of the Bantu will have an impact on his current level of trust but not directly on quality of health related infrastructures in the Fon territory where he or she lives. Inherited trust is thus assumed not to be correlated with the error term.

Inherited trust is calculated from historical ethnic data on settlement patterns in Africa, taken from the ethnographic atlas of Murdock (1967), which is used to map the territory of ethnic groups before the formation of modern countries. We delimit 282 historical ethnic territories, as shown in Figure 3. We proxy inherited trust by the average trust level in his/her ethnic group's homeland (Almost 48 percent of individuals in our sample have moved from their ethnic group homeland). For example, a member of the Bantu ethnic group who now lives in a Fon ethnic group homeland will inherit trust given by the standardized level of trust in the Bantu homeland. The main difficulty here is that some ethnic groups have split up into different sub-groups, while others have completely changed their names. We here use the information from Nunn and Wantchekon (2011) (available at http: //scholar.harvard.edu/nunn/pages/data-0) to link current ethnic groups to those identified by Murdock. We calculate inherited trust in the ethnic homeland as the average trust level of the individuals who still live there (e.g. the average trust levels of Bantus who still live in the Bantu homeland). Inherited trust at the district level is the average of respondent's inherited trust, weighted by the relative size of each ethnic group in the district. Since we wish to compare two measures of trust, trust in neighbors and generalized trust, we compute the two corresponding types of Inherited trust, Inherit_NEIGH and Inherit_GVS.

A problem with instruments is caused by the selection of "weak" instruments, i.e. instruments that are poor predictors of the endogenous variable we wish to instrument. To address this issue we run the first stage regression (4) and compute the corresponding Fstatistics. A common rule of thumb is to consider as valid instruments for which the Fstatistic, against the null, that the excluded instruments are irrelevant in the first-stage regression, should be larger than 10. The results of the first-stage regression are shown in Table 2. The values of the F-statistics for inherited trust are 201 and 42 for trust in neighborhood and generalized trust respectively. A one standard deviation rise in the level of inherited generalized trust leads to a 0.233 standard deviation increase in the predicted value of current district generalized trust. The result is even stronger for trust in neighbors, with an analogous figure of 0.562 standard deviations. We can thus safely rule out any problem resulting from weak instruments here. 


\section{Results}

\subsection{Social capital and Health}

Table 3 estimates equation 1 without the districts level controls Yd. The first part of the table shows the results of generalized trust on the quality of health centers. The estimated coefficients are positive and significant for three of the seven health-quality indicators. Trust in neighbor's turns out to be more strongly correlated with our dependent variable, with six of the seven health-quality indicators showing significant correlations. We then control for a range of district characteristics in Table 4 for generalized trust and Table 5 for trust in neighbors. Trust remains an important determinant of health-center quality: trust in neighbors is now significant for all seven health-center quality measures. We also find that five of our control variables are important for the quality of the health centers: wealth, participation in religious groups, the proportion of individuals in the district who participate in raising issues, age and membership in community-based organizations. Participation in local religious groups and membership in community-based organization are negatively correlated with the health-quality variables, while the correlation with wealth is positive.

We now turn to the IV estimation results in Table 6 for trust in neighbors and generalized trust (in the first and second parts of the table respectively). The Durbin-Wu-Housman statistics here show that we cannot reject the null hypothesis that the OLS estimations are consistent for Expensive services (EXP), Doctor Absenteeism (DABS) and Illegal Payments (ILP). However, for the estimation of the other health-center quality indicators, the IV estimations are preferred. The results reveal a positive and significant effect of trust on health-center quality. The IV coefficients are both more significant and larger, suggesting that OLS underestimates the true effect of trust on health-center quality. For example, we find that a one standard deviation increase in the level of localized trust leads to a 0.221 standard deviation decrease in the predicted value of doctor absenteeism, a 0.307 standard deviation decrease in the predicted value of waiting time, a 0.301 standard deviation decrease in the predicted value of bribes, 0.330 standard deviation decrease in the predicted value of problems of poor facilities. This a comforting result since, as expected, trust in neighbors plays a larger role than generalized trust regarding the ability to produce local public goods such as health centers. 


\subsection{Alternative sample: social capital and drinking water}

The previous tests are based on subjective assessments of health variables (respondents simply indicates their perception of various quantity). We would like to check that our previous finding survive if we consider objective data on a different health issue. We here focus on water access for at least three reasons. First, data are available in many of the districts we here considered. Second, water access is both a private good (e.g. filtering water at home) and a local public good (e.g. maintaining the pipe network). So we can test whether household are making individual effort to improve water quality and measure whether water infrastructures are present at the district level. Last, unlike our previous measures, the presence of water infrastructure (e.g. pipes) is objectively measured in the present dataset.

We first test the relationship between our social-capital measures and the water-treatment index at the household level, as expressed in equation 2. We estimate this equation using country fixed effects and controlling for a number of household and district-level characteristics. Table 7 shows coefficients from OLS estimation using trust in neighbors in column 1, and generalized trust in column 2. The estimated coefficients are insignificant for both trust variables suggesting that there is no relation between social capital, as measured by generalized and localized trust, and the water- treatment index. Wealthier, more-educated and younger households are more likely to adopt the best health-related behaviors and hygienic practices: the effects of these variables are substantial and very significant $(p<0.001)$.

We now turn to the IV estimates which appear in the third and fourth columns of Table 7. Before interpreting the results, we first test the exogeneity of our instruments via Durbin and Wu- Hausman tests: the relevant p-values appear at the bottom of Table 7. The p-values of the tests indicate the presence of endogeneity and reject the null hypothesis that OLS is consistent: the IV estimates are thus preferable. The estimated coefficients in the IV regressions are only significant for the level of trust in neighbors, suggesting that OLS estimates there are biased downwards. The estimated localized-trust coefficient rises from 0.030 to 0.080 . A one standard deviation increase in the level of localized trust leads to a 0.080 standard deviation increases in the predicted value of water-treatment. The effect of generalized trust remains insignificant, however.

Table 8 displays the effect of social capital on access to improved safe drinking water, as expressed in equation 1. The OLS estimates in column 1 for trust in neighbors and column 3 for generalized trust are insignificant: only urbanization and wealth seem to explain access to improved drinking water. However, the Durbin and Wu-Hausman tests for the endogeneity of the social-capital variable reveal that the social-capital coefficients are 
endogenous, so that the OLS results are biased. The trust coefficients in the IV regressions are positive and significant: localized trust becomes significant at 99 percent level and generalized trust at 90 percent. A one standard deviation increase in the level of localized trust leads to a 0.330 standard deviation increase in the access on clean water, with an analogous figure for generalized trust of 0.179 .

Overall, our results confirm the hypothesis that trust has a causal impact on access to drinkable water. As expected we find a greater effect for localized trust. The use of instrumental variables suggests that the effect of trust is causal.

\subsection{Robustness checks: historical controls}

To satisfy the exclusion-restriction condition inherited trust should only affect the health indicators via the actual level of trust. This condition is not met if inherited trust affects health quality through other sources, namely local institutions or some historical variables. To see if the exclusion restriction condition holds, we perform a battery of tests. We identify historical variables through which inherited trust may affect the quality of health care (the former presence of colonizers, railways and the presence of a pre-colonial city, the deadliness of the disease environment and a measure of the historic exposure of the territory to the transatlantic and Indian Ocean slave trade). If the effect of trust on health quality disappears with the inclusion of these historical variables, this suggests that the effects found in the previous estimates are mostly driven by the omission of these historical variables. Results are reported in Tables 9 and 10. The inclusion of these additional controls turns out to have a very limited impact. This reinforces our assumption that inherited trust is indeed exogenous. 


\section{Conclusion}

This paper has considered the determinants of community capacity to manage health care in developing countries, focusing on the role of trust. Our results add to the previous literature by considering the specific case of developing countries, and particularly Sub-Saharan African countries. We showed that trust, viewed as a measure of social capital, has a positive and causal impact on health. The magnitude of the effect is large, with very significant coefficients.

By comparing the effect of trust on different health indicators we can provide insights on the social process that converts social capital into health. For instance, maintaining facilities such a well or boreholes, entails a public good dimension. If too much free riding is at work, the quality of these facilities will decrease. Since more social capital means more such public goods, social capital is likely to reduce free-riding. On the other hand, using treating water at home is a private good. We can thus conjecture that the positive effect of social capital found there follows another channel, most likely the diffusion of sound social norms among local networks. Whatever the channels that are followed, or the goods that are considered, social capital appears as a key determinant of the success of local health-care systems.

If we go back to our introductory example of barefoot doctors, it is of interest to note that the success of this initiative relied on social capital, among other things. For example, local communities in China at the time decided by themselves what their health-care priorities were. Barefoot doctors were thus efficient in part because communities were able to use their limited health-care resources where they were the most efficient.

As a consequence, policies to increase social capital would seem relevant for decision makers who aim to improve health in Africa. One important question is thus what such policies would look like. There is no clear consensus regarding the best way of enhancing social capital. Especially if we think about rural Africa, there are only limited channels via which policies can be implemented in the field. It is possible that cost-effective ways of increasing social capital can be found. We can perhaps think of promoting volunteering among the young or providing basic training to leaders regarding consensus-building. Such strategies have for instance been found to be effective in Honduras (Brune and Bossert, 2009). The work presented here suggests that these are important questions to be addressed in future research. 


\section{References}

Algan, Y. and P. Cahuc (2013). Trust, growth and happiness: New evidence and policy implications. Handbook of Economic Growth eds Philippe Aghion and Steven Durlauf 2A.

Algan, Y., \& Cahuc, P. (2010). Inherited trust and growth. The American Economic Review, 2060-2092.

Borgonovi, F. (2010). A life-cycle approach to the analysis of the relationship between social capital and health in Britain. Social Science \& Medicine 71 (11), 1927-1934.

Brown, T. T., R. M. Scheffler, S. Seo, and M. Reed (2006). The empirical relationship between community social capital and the demand for cigarettes. Health Economics 15 (11), 1159-1172.

Brune, N. E. and T. Bossert (2009). Building social capital in post-conflict communities: Evidence from Nicaragua. Social Science \& Medicine 68 (5), 885-893.

Carpiano, R. M. and L. M. Fitterer (2014). Questions of trust in health research on social capital: What aspects of personal network social capital do they measure? Social Science \& Medicine 116, 225-234.

Cattell, V. (2001). Poor people, poor places, and poor health: the mediating role of social networks and social capital. Social science \& medicine, 52(10), 1501-1516.

Caughy, M. O. B., O’Campo, P. J., \& Muntaner, C. (2003). When being alone might be better: neighborhood poverty, social capital, and child mental health. Social science and medicine, 57(2), 227-237.

Coleman, J. (1990). Foundations of Social Theory. Cambridge, MA: Harvard University Press.

Hawe, P., \& Shiell, A. (2000). Social capital and health promotion: a review. Social science \& medicine, 51(6), 871-885.

D’Hombres, B., L. Rocco, M. Suhrcke, C. Haerpfer, and M. McKee (2009). The influence of social capital on health in eight former soviet countries: why does it differ? Journal of epidemiology and community health, jech-2009.

D’Hombres, B., L. Rocco, M. Suhrcke, and M. McKee (2010). Does social capital determine health? evidence from eight transition countries. Health Economics 19 (1), 56-74.

Dupas, P. (2011). Health behavior in developing countries. Annual Review of Economics 3, $425-449$.

Ensor, T. and S. Cooper (2004). Overcoming barriers to health service access: influencing the demand side. Health Policy and Planning 19 (2), 69-79. 
Gory akin, Y., M. Suhrcke, L. Rocco, B. Roberts, and M. McKee (2014). Social capital and self- reported general and mental health in nine former soviet union countries. Health Economics, Policy, and Law 9 (1), 1-24.

Herian, M. N., L. Tay, J. A. Hamm, and E. Diener (2014). Social capital, ideology, and health in the United States. Social Science \& Medicine 105, 30-37.

Kennelly, B., O’Shea, E., \& Garvey, E. (2003). Social capital, life expectancy and mortality: a cross-national examination. Social Science \& Medicine, 56(12), 2367-2377.

Islam, M. K., J. Merlo, I. Kawachi, M. Lindstrom, and U.-G. Gerdtham (2006). Social capital and health: Does egalitarianism matter? a literature review. International Journal for Equity in Health 5 (1), Article 3.

Jyotsna, J. and E. Somanathan (2008). The importance of being informed: Experimental evidence on demand for environmental quality. Journal of Development Economics, 87 (1), $14-28$.

Murdock, G. P. (1967). Ethnographic Atlas: A Summary. Pittsburgh: The University of Pittsburgh Press.

Nauenberg, E., A. Laporte, and L. Shen (2011). Social capital, community size and utilization of health services: A lagged analysis. Health Policy 103 (1), 38-46.

Nunn, N. and L. Wantchekon (2011). The Slave Trade and the Origins of Mistrust in Africa. American Economic Review, 101(7): 3221-52.

Putnam, R. (2000). Bowling alone: The collapse and revival of American community. New York: Simon and Schuster.

Rocco, L. (2014). Trust me, you will be in better health. Health Policy 116 (1), 123-132.

Rocco, L., E. Fumagalli, and M. Suhrcke (2014). From social capital to health-and back. Health Economics 23 (5), 586-605.

Ronconi, L., T. T. Brown, and R. M. Scheffler (2012). Social capital and self-rated health in Argentina. Health Economics 21 (2), 201-208.

Sobel, J. (2002). Can we trust social capital? Journal of Economic Literature 40 (1), 139154.

Uslaner, E. (2008). Where you stand depends upon where your grandparents sat:the inheritability of generalized trust. Public Opinion Quarterly 72 (4), 725-740.

Yoon, J. and T. T. Brown (2011). Does the promotion of community social capital reduce obesity risk? Journal of Socio-Economics 40 (3), 296-305. 
Appendices 
Table 1: List of variables and summary statistics

\begin{tabular}{|c|c|c|c|c|c|c|}
\hline Variable & Description & Mean & Std. Dev. & $\mathbf{N}$ & Min & Max \\
\hline EXP & Health center too expensive & 0.982 & 0.650 & 1339 & 0 & 3 \\
\hline MES & Lack of medicines/supplies & 0.119 & 0.693 & 1334 & 0 & 3 \\
\hline DABS & Doctor absenteeism & 1.048 & 0.623 & 1336 & 0 & 3 \\
\hline LWA & Long waiting time & 1.534 & 0.670 & 1335 & 0 & 3 \\
\hline PFA & Dirty facilities & 0.738 & 0.584 & 1335 & 0 & 3 \\
\hline ILP & Illegal Payments & 0.744 & 0.693 & 1293 & 0 & 3 \\
\hline LREP & Lack of attention/respect & 1.039 & 0.607 & 1336 & 0 & 3 \\
\hline WTI & water-treatment index & 0.02 & 0.280 & $1 \mathrm{E}+05$ & 0,55 & 2,58 \\
\hline Prop well & $\%$ access to protected water source & 0.474 & 0.332 & 659 & 0 & 1 \\
\hline Trust_GVS & Level of generalized trust & 0.185 & 0.183 & 1327 & 0 & 1 \\
\hline Trst NEIGH & Level of trust in neighbors & 1.744 & 0.563 & 1263 & 0 & 3 \\
\hline $\mathrm{EFI}$ & District level of ethnic fractionalization & 0.313 & 0.279 & 1181 & 0 & 0,9 \\
\hline Dist_wealth & District level wealth index & 0.014 & 0.429 & 1355 & $-0,77$ & 1,64 \\
\hline Median_age & Median age & 34.785 & 7.971 & 1291 & 19 & 72 \\
\hline Prop_male & Proportion of male & 0.493 & 0.117 & 1292 & 0 & 1 \\
\hline Prop_educated & Proportion of educated & 0.643 & 0.317 & 1355 & 0 & 1 \\
\hline Prop protestant & Proportion of Protestants & 0.123 & 0.177 & 1292 & 0 & 1 \\
\hline Prop urban & Proportion in urban areas & 0.310 & 0.421 & 1292 & 0 & 1 \\
\hline Atten_protest & Proportion attend protests & 0.503 & 0.224 & 1355 & 0 & 1 \\
\hline Prop atten rising & Proportion raise issues & 0.831 & 0.174 & 1355 & 0 & 1 \\
\hline Prop tten meet & Proportion attending in meetings & 0.898 & 0.139 & 1355 & 0,25 & 1 \\
\hline Prop memb cbo & Proportion of member $\mathrm{CBO}$ & 0.328 & 0.211 & 1355 & 0 & 1 \\
\hline Prop memb religious & Proportion in religious groups & 0.756 & 0.212 & 1355 & 0 & 1 \\
\hline Road & Number of paved roads & 0.366 & 0.43 & 1355 & 0 & 1 \\
\hline Recrea facilities & Number of recreational facilities & 0.555 & 0.435 & 1333 & 0 & 1 \\
\hline Male (DHS) & $\%$ of male respondents & 79.43 & & $1 \mathrm{E}+05$ & 0 & 1 \\
\hline Age (DHS) & Age of respondent & 47.31 & 15.170 & $1 \mathrm{E}+05$ & 18 & 99 \\
\hline Wealth_index (DHS) & Househould's DHS wealth index & 2.882 & 1.410 & $1 \mathrm{E}+05$ & 1 & 5 \\
\hline No school (DHS) & $\%$ without formal education & 45.41 & & $1 \mathrm{E}+05$ & 0 & 1 \\
\hline Primary school (DHS) & $\%$ completed primary & 7.22 & & $1 \mathrm{E}+05$ & 0 & 1 \\
\hline Secondary (DHS) & $\%$ completed secondary school & 4.09 & & $1 \mathrm{E}+05$ & 0 & 1 \\
\hline Higher (DHS) & $\%$ higher education & 2.810 & & $1 \mathrm{E}+05$ & 0 & 1 \\
\hline
\end{tabular}

Unless specified otherwise, data come the Afrobarometer survey. (DHS) indicates that data come from the Demographic and Health Survey 
Table 2: First-stage estimation

\begin{tabular}{|c|c|c|c|c|}
\hline \multirow[b]{2}{*}{ Inherit NEIGH } & \multicolumn{2}{|c|}{ Trust NEIGH } & \multicolumn{2}{|c|}{ Trust GVS } \\
\hline & $.824 * * *$ & $(.058)$ & & \\
\hline Inherit GVS & & & $1.204 * * *$ & $(.185)$ \\
\hline Fractionalization & .001 & $(.053)$ & -.009 & $(.059)$ \\
\hline Wealth & $-.225 * * *$ & $(.059)$ & $-.285 * * *$ & $(.060)$ \\
\hline Median age & $.004^{*}$ & $(.003)$ & .002 & $(.003)$ \\
\hline Prop educated & -.049 & $(.087)$ & $-.259 * *$ & $(.093)$ \\
\hline Prop urban & -.065 & $(.045)$ & -.045 & $(.048)$ \\
\hline Prop attend protest & -.090 & $(.085)$ & -.122 & $(.091)$ \\
\hline Prop raising issue & -.071 & $(.141)$ & -.127 & (.147) \\
\hline Prop meeting & .001 & $(.183)$ & -.034 & $(.185)$ \\
\hline Prop member $\mathrm{CBO}$ & .105 & $(.088)$ & $.215^{* *}$ & $(.091)$ \\
\hline Prop religious & .098 & $(.089)$ & .007 & (.095) \\
\hline Road & -.063 & $(.042)$ & -.064 & $(.046)$ \\
\hline Recrea facilities & .051 & $(.036)$ & .052 & $(.039)$ \\
\hline Constant & .216 & $(.221)$ & $1.490 * * *$ & $(.208)$ \\
\hline F-test & \multicolumn{2}{|c|}{$201.10 * * *$} & \multicolumn{2}{|c|}{$42.18 * * *$} \\
\hline Adj. $R^{2}$ & \multicolumn{2}{|c|}{.452} & \multicolumn{2}{|c|}{.353} \\
\hline No. of cases & \multicolumn{2}{|c|}{1023} & \multicolumn{2}{|c|}{1023} \\
\hline
\end{tabular}


Table 3: OLS estimation of the effect of the level of trust on health-center quality

EXP MES DABS LWA PFA ILP LREP

\begin{tabular}{|c|c|c|c|c|c|c|c|}
\hline Trust_GVS & $\begin{array}{l}.008 \\
(.0998)\end{array}$ & $\begin{array}{l}.197 * \\
(.1056)\end{array}$ & $\begin{array}{l}.173 \\
(.1066)\end{array}$ & $\begin{array}{l}.329 * * \\
(.1095)\end{array}$ & $\begin{array}{l}.142 \\
(.0943)\end{array}$ & $\begin{array}{l}-.234 \\
(.1569)\end{array}$ & $\begin{array}{l}.390 * * * \\
(.0984)\end{array}$ \\
\hline Constant & $\begin{array}{l}-1.612^{* * *} \\
(.0860)\end{array}$ & $\begin{array}{l}-1.483 * * * \\
(.0954)\end{array}$ & $\begin{array}{l}-.745 * * * \\
(.0599)\end{array}$ & $\begin{array}{l}-1.177 * * * \\
(.0747)\end{array}$ & $\begin{array}{l}-.616^{* * *} \\
(.0667)\end{array}$ & $\begin{array}{l}-.638 * * * \\
(.0815)\end{array}$ & $\begin{array}{l}-1.180 * * * \\
(.0746)\end{array}$ \\
\hline Adj. $R^{2}$ & .285 & .160 & .162 & .236 & .151 & .071 & .191 \\
\hline No. of cases & 1256 & 1251 & 1253 & 1252 & 1252 & 1254 & 1253 \\
\hline
\end{tabular}

\begin{tabular}{lllllllll} 
Trust_NEIGH & .039 & $.075^{*}$ & $.081^{* *}$ & $.136^{* * *}$ & $.149^{* * *}$ & $.131^{* *}$ & $.204 * * *$ \\
& $(.0358)$ & $(.0402)$ & $(.0369)$ & $(.0394)$ & $(.0360)$ & $(.0507)$ & $(.0358)$ \\
Constant & $-1.675^{* * *}$ & $-1.548^{* * *}$ & $-.826^{* * *}$ & $-1.303 * * *$ & $-.819 * * *$ & $-.928^{* * *}$ & $-1.399 * * *$ \\
& $(.1010)$ & $(.1107)$ & $(.0793)$ & $(.0927)$ & $(.0832)$ & $(.1064)$ & $(.0887)$ \\
& & & & & & \\
\hline Adj. $\mathrm{R}^{2}$ & .261 & .143 & .187 & .268 & .167 & .204 & .209 \\
No. Obs & 1067 & 1062 & 1064 & 1063 & 1063 & 1063 & 1064
\end{tabular}

Standard errors are in parentheses. All regressions are OLS with country fixed effects. The dependent variables are the variables describing the quality of health centers in the district. * Significant at $90 \%$, * Significant at $95 \%$ and *** Significant at $99 \%$. 
Table 4: OLS estimation of the effect of generalized trust on health-center quality

\begin{tabular}{|c|c|c|c|c|c|c|c|}
\hline & EXP & MES & DABS & LWA & PFA & ILP & LREP \\
\hline Trust_GVS & $\begin{array}{l}.042 \\
(.112)\end{array}$ & $\begin{array}{l}.081^{* *} \\
(.119)\end{array}$ & $\begin{array}{l}.061^{*} \\
(.120)\end{array}$ & $\begin{array}{l}.098^{* *} \\
(.124)\end{array}$ & $\begin{array}{l}.026 \\
(.109)\end{array}$ & (.001 & $\begin{array}{l}.110^{* *} \\
(.112)\end{array}$ \\
\hline Wealth & $\begin{array}{l}.165 * * \\
(.064)\end{array}$ & $\begin{array}{l}.244 * * \\
(.074)\end{array}$ & $\begin{array}{l}.135^{*} \\
(.075)\end{array}$ & $\begin{array}{l}.080 \\
.082)\end{array}$ & $\begin{array}{l}.132 * \\
(.068)\end{array}$ & $\begin{array}{l}.170 \\
(.124)\end{array}$ & $\begin{array}{l}.059 \\
.075)\end{array}$ \\
\hline Median age & $\begin{array}{l}.000 \\
(.003)\end{array}$ & $\begin{array}{l}.003 \\
(.003)\end{array}$ & $\begin{array}{l}.004 \\
(.003)\end{array}$ & $\begin{array}{l}.003 \\
.003)\end{array}$ & $\begin{array}{l}.005^{*} \\
(.002)\end{array}$ & $\begin{array}{l}-.005 \\
(.005)\end{array}$ & $\begin{array}{l}.008^{* *} \\
(.003)\end{array}$ \\
\hline Prop educated & $\begin{array}{l}.155 \\
. .099)\end{array}$ & $\begin{array}{l}-.102 \\
(.104)\end{array}$ & $\begin{array}{l}.111 \\
(.096)\end{array}$ & $\begin{array}{l}.052 \\
(.099)\end{array}$ & $\begin{array}{l}.051 \\
(.092)\end{array}$ & $\begin{array}{l}-.220 \\
(.175)\end{array}$ & $\begin{array}{r}.078 \\
(.099)\end{array}$ \\
\hline Fractionalization & $\begin{array}{l}-.042 \\
(.070)\end{array}$ & $\begin{array}{l}-.104 \\
(.083)\end{array}$ & $\begin{array}{l}.113 \\
(.074)\end{array}$ & $\begin{array}{r}.013 \\
(.071)\end{array}$ & $\begin{array}{l}-.007 \\
(.070)\end{array}$ & $\begin{array}{l}-.117 \\
(.112)\end{array}$ & $\begin{array}{l}.000 \\
(.068)\end{array}$ \\
\hline Prop urban & $\begin{array}{l}-.027 \\
(.049)\end{array}$ & $(. .010)$ & $\begin{array}{l}-.030 \\
(.056)\end{array}$ & $\begin{array}{l}-.098 \\
(.060)\end{array}$ & $\begin{array}{l}-.038 \\
(.054)\end{array}$ & $\begin{array}{l}-.046 \\
(.085)\end{array}$ & $\begin{array}{l}-.090^{*} \\
(.053)\end{array}$ \\
\hline Prop att. protest & $\begin{array}{l}-.053 \\
(.096)\end{array}$ & $\begin{array}{l}-.015 \\
(.116)\end{array}$ & $\begin{array}{l}.032 \\
(.108)\end{array}$ & $\begin{array}{l}.081 \\
(.109)\end{array}$ & $\begin{array}{l}.082 \\
(.101)\end{array}$ & $\begin{array}{l}.026 \\
(.158)\end{array}$ & $\begin{array}{l}-.056 \\
(.101)\end{array}$ \\
\hline Prop raising issue & $\begin{array}{l}-.101 \\
(.157)\end{array}$ & $\begin{array}{r}-.427 * * \\
(.187)\end{array}$ & $\begin{array}{r}-.475^{* *} \\
(.182)\end{array}$ & $\begin{array}{l}-.292 \\
(.181)\end{array}$ & $\begin{array}{r}-.545^{* *} \\
(.178)\end{array}$ & $\begin{array}{l}-.538^{*} \\
(.281)\end{array}$ & $\begin{array}{l}-.276 \\
(.180)\end{array}$ \\
\hline Prop att. meeting & $\begin{array}{l}-.089 \\
(.184)\end{array}$ & $\begin{array}{l}-.369 \\
(.233)\end{array}$ & $\begin{array}{r}.304 \\
(.251)\end{array}$ & $\begin{array}{l}.105 \\
(.249)\end{array}$ & $\begin{array}{l}.281 \\
(.225)\end{array}$ & $\begin{array}{r}.529 \\
(.353)\end{array}$ & $\begin{array}{l}-.070 \\
(.229)\end{array}$ \\
\hline Prop memb. CBO & $\begin{array}{l}-.088 \\
(.103)\end{array}$ & $\begin{array}{r}-.265^{* *} \\
(.120)\end{array}$ & $\begin{array}{r}-.209^{* *} \\
(.106)\end{array}$ & $\begin{array}{l}-.183^{*} \\
(.110)\end{array}$ & $\begin{array}{l}-.195^{*} \\
(.100)\end{array}$ & $\begin{array}{l}-.222 \\
(.163)\end{array}$ & $\begin{array}{l}.010 \\
(.106)\end{array}$ \\
\hline Prop memb. religious & $\begin{array}{l}.320 * * \\
(.114)\end{array}$ & $\begin{array}{r}.453^{* * * *} \\
(.126)\end{array}$ & $\begin{array}{l}.065 \\
(.119)\end{array}$ & $\begin{array}{l}.076 \\
(.114)\end{array}$ & (.116) & $\begin{array}{l}.297^{*} \\
(.178)\end{array}$ & $\begin{array}{l}.087 \\
(.116)\end{array}$ \\
\hline Road & $\begin{array}{l}.023 \\
(.047)\end{array}$ & $\begin{array}{l}.031 \\
(.055)\end{array}$ & $\begin{array}{l}.046 \\
(.051)\end{array}$ & $\begin{array}{l}-.013 \\
(.055)\end{array}$ & $\begin{array}{r}-.112^{* * *} \\
(.052)\end{array}$ & $\begin{array}{l}.046 \\
(.093)\end{array}$ & $\begin{array}{l}-.070 \\
(.050)\end{array}$ \\
\hline Recrea facilities & $\begin{array}{l}.030 \\
(.040)\end{array}$ & $\begin{array}{l}-.088^{*} \\
(.048)\end{array}$ & $\begin{array}{r}-.042 \\
(.042)\end{array}$ & $\begin{array}{l}.041 \\
(.044)\end{array}$ & $\begin{array}{r}-.017 \\
(.042)\end{array}$ & $\begin{array}{l}-.094 \\
(.070)\end{array}$ & $\begin{array}{r}.013 \\
(.041)\end{array}$ \\
\hline Constant & $\begin{array}{r}-1.685^{* * *} \\
(.219)\end{array}$ & $\begin{array}{r}-.961^{* * *} \\
(.252)\end{array}$ & $\begin{array}{r}-.796 * * * \\
(.240)\end{array}$ & $\begin{array}{r}-1.204 * * * \\
(.243)\end{array}$ & $\begin{array}{r}-.590 * * \\
(.222)\end{array}$ & $\begin{array}{l}-.456 \\
(.380)\end{array}$ & $\begin{array}{r}-1.152 * * * \\
(.226)\end{array}$ \\
\hline $\begin{array}{l}\text { Adj. } R^{2} \\
\text { No. of cases }\end{array}$ & $\begin{array}{r}.300 \\
1064 \\
\end{array}$ & $\begin{array}{r}.199 \\
1063 \\
\end{array}$ & $\begin{array}{l}.202 \\
1061 \\
\end{array}$ & $\begin{array}{l}.271 \\
1060 \\
\end{array}$ & $\begin{array}{l}.177 \\
1060 \\
\end{array}$ & $\begin{array}{l}.065 \\
1061 \\
\end{array}$ & $\begin{array}{c}.222 \\
1061 \\
\end{array}$ \\
\hline
\end{tabular}

* Significant at $90 \%,{ }^{* *}$ Significant at $95 \%$ and $* *$ Significant at $99 \%$. Only standardized coefficients are reported for the variable trust in neighbors. 
Table 5: OLS estimation of the effect of trust in neighbors on health-center quality

\begin{tabular}{|c|c|c|c|c|c|c|c|}
\hline & EXP & MES & DABS & LWA & PFA & ILP & LREP \\
\hline Trust_NEIGH & $\begin{array}{l}.112 * * \\
(.040)\end{array}$ & $\begin{array}{l}.093 * * \\
(.044)\end{array}$ & $\begin{array}{l}.112 * * \\
(.044)\end{array}$ & $\begin{array}{r}.137 * * * \\
(.046)\end{array}$ & $\begin{array}{r}.182^{* * * *} \\
(.042)\end{array}$ & $\begin{array}{l}.187^{* *} \\
(.061)\end{array}$ & $\begin{array}{r}.213^{* * *} \\
(.041)\end{array}$ \\
\hline Wealth & $\begin{array}{l}.197 * * \\
(.066)\end{array}$ & $\begin{array}{r}.261 * * * \\
(.074)\end{array}$ & $\begin{array}{l}.162^{* *} \\
(.076)\end{array}$ & $\begin{array}{l}.112 \\
.083)\end{array}$ & $\begin{array}{l}.183 * * \\
(.070)\end{array}$ & $\begin{array}{l}.236^{*} \\
(.123)\end{array}$ & $\begin{array}{l}.110 \\
(.076)\end{array}$ \\
\hline Median age & $\begin{array}{l}.000 \\
(.003)\end{array}$ & $\begin{array}{l}.003 \\
(.003)\end{array}$ & $\begin{array}{l}.004 \\
(.003)\end{array}$ & $\begin{array}{l}.003 \\
.003)\end{array}$ & $\begin{array}{l}.005^{*} \\
(.002)\end{array}$ & $\begin{array}{r}-.004 \\
(.005)\end{array}$ & $\begin{array}{l}.008 * * \\
(.003)\end{array}$ \\
\hline Prop educated & $\begin{array}{l}.195^{* *} \\
(.099)\end{array}$ & $\begin{array}{l}-.066 \\
(.106)\end{array}$ & $\begin{array}{l}.149 \\
(.099)\end{array}$ & $\begin{array}{l}.100 \\
(.100)\end{array}$ & $\begin{array}{l}.116 \\
.092)\end{array}$ & $\begin{array}{l}-.145 \\
(.177)\end{array}$ & $\begin{array}{l}.150 \\
(.099)\end{array}$ \\
\hline Fractionalization & $\begin{array}{l}-.040 \\
(.070)\end{array}$ & $\begin{array}{l}-.102 \\
(.083)\end{array}$ & (.116 & $\begin{array}{r}.017 \\
(.071)\end{array}$ & $\begin{array}{l}-.003 \\
(.069)\end{array}$ & $(.112)$ & $\begin{array}{r}.005 \\
(.066)\end{array}$ \\
\hline Prop urban & $\begin{array}{l}-.021 \\
(.050)\end{array}$ & $\begin{array}{l}-.004 \\
(.058)\end{array}$ & $\begin{array}{l}-.023 \\
(.057)\end{array}$ & $\begin{array}{l}-.088 \\
(.061)\end{array}$ & $\begin{array}{l}-.029 \\
(.054)\end{array}$ & $\begin{array}{l}-.039 \\
(.085)\end{array}$ & $\begin{array}{l}-.077 \\
(.054)\end{array}$ \\
\hline Prop attend protest & $\begin{array}{l}-.039 \\
(.095)\end{array}$ & $\begin{array}{l}-.010 \\
(.115)\end{array}$ & $\begin{array}{l}.044 \\
(.107)\end{array}$ & $\begin{array}{l}.093 \\
(.110)\end{array}$ & $\begin{array}{l}.113 \\
(.098)\end{array}$ & $\begin{array}{l}.072 \\
(.156)\end{array}$ & $\begin{array}{l}-.032 \\
(.099)\end{array}$ \\
\hline Prop raising issue & $\begin{array}{l}-.092 \\
(.155)\end{array}$ & $\begin{array}{r}-.418^{* *} \\
(.186)\end{array}$ & $\begin{array}{r}-.466 * * \\
(.183)\end{array}$ & $\begin{array}{c}-.282 \\
(.181)\end{array}$ & $\begin{array}{r}-.524 * * \\
(.176)\end{array}$ & $\begin{array}{l}-.508^{*} \\
(.276)\end{array}$ & $\begin{array}{r}-.258 \\
(.180)\end{array}$ \\
\hline Prop att. meeting & $\begin{array}{l}-.095 \\
(.182)\end{array}$ & $\begin{array}{l}-.372 \\
(.233)\end{array}$ & $\begin{array}{r}.297 \\
(.254)\end{array}$ & $\begin{array}{l}.097 \\
(.255)\end{array}$ & . .264 & $\begin{array}{r}.508 \\
(.348)\end{array}$ & $\begin{array}{l}-.084 \\
(.236)\end{array}$ \\
\hline Prop memb $\mathrm{CBO}$ & $\begin{array}{l}-.108 \\
(.103)\end{array}$ & $\begin{array}{r}-.270^{* *} \\
(.120)\end{array}$ & $\begin{array}{r}-.222 * * \\
.106)\end{array}$ & $\begin{array}{l}-.197 * \\
(.109)\end{array}$ & $\begin{array}{r}-.228 * * \\
(.099)\end{array}$ & $\begin{array}{l}-.275^{*} \\
(.164)\end{array}$ & $\begin{array}{l}-.017 \\
(.103)\end{array}$ \\
\hline Prop memb. religious & $\begin{array}{l}.320^{* *} \\
(.113)\end{array}$ & $\begin{array}{r}.442 * * * \\
(.125)\end{array}$ & $\begin{array}{l}.061 \\
(.117)\end{array}$ & $\begin{array}{l}.066 \\
(.112)\end{array}$ & $\begin{array}{l}.125 \\
(.112)\end{array}$ & $\begin{array}{l}.322^{*} \\
(.178)\end{array}$ & $\begin{array}{l}.080 \\
(.112)\end{array}$ \\
\hline Road & $\begin{array}{l}.026 \\
(.046)\end{array}$ & $\begin{array}{l}.025 \\
(.055)\end{array}$ & $\begin{array}{r}.045 \\
(.051)\end{array}$ & $\begin{array}{l}-.018 \\
(.055)\end{array}$ & $\begin{array}{l}-.102 * \\
(.052)\end{array}$ & $\begin{array}{l}.071 \\
(.092)\end{array}$ & $\begin{array}{l}-.070 \\
(.049)\end{array}$ \\
\hline Recrea facilities & $\begin{array}{l}.028 \\
(.040)\end{array}$ & $\begin{array}{l}-.092^{*} \\
(.048)\end{array}$ & $\begin{array}{l}-.045 \\
(.042)\end{array}$ & $\begin{array}{l}.036 \\
(.044)\end{array}$ & $\begin{array}{l}-.019 \\
(.042)\end{array}$ & $\begin{array}{r}-.094 \\
(.070)\end{array}$ & $\begin{array}{l}.007 \\
(.040)\end{array}$ \\
\hline Constant & $\begin{array}{r}-1.864 * * * \\
(.221)\end{array}$ & $\begin{array}{r}-1.052 * * * \\
(.259)\end{array}$ & $\begin{array}{r}-.946 * * * \\
(.250)\end{array}$ & $\begin{array}{r}-1.368^{* * * *} \\
(.250)\end{array}$ & $\begin{array}{r}-.916^{* * * *} \\
(.222)\end{array}$ & $\begin{array}{r}-.924 * * \\
(.382)\end{array}$ & $\begin{array}{r}-1.444^{* * * *} \\
(.230)\end{array}$ \\
\hline $\begin{array}{l}\text { Adj. } R^{2} \\
\text { No. of cases }\end{array}$ & $\begin{array}{c}.307 \\
1064 \\
\end{array}$ & $\begin{array}{c}.199 \\
1063 \\
\end{array}$ & $\begin{array}{c}.208 \\
1061 \\
\end{array}$ & $\begin{array}{r}.276 \\
1060 \\
\end{array}$ & $\begin{array}{r}.199 \\
\quad 1060 \\
\end{array}$ & $\begin{array}{r}.073 \\
106 \\
\end{array}$ & .242 \\
\hline
\end{tabular}

* Significant at $90 \%, * *$ Significant at $95 \%$ and $* *$ Significant at $99 \%$. Only standardized coefficients are reported for the variable trust in neighbors. 
Figure 1: Distribution of district-level generalized trust by country

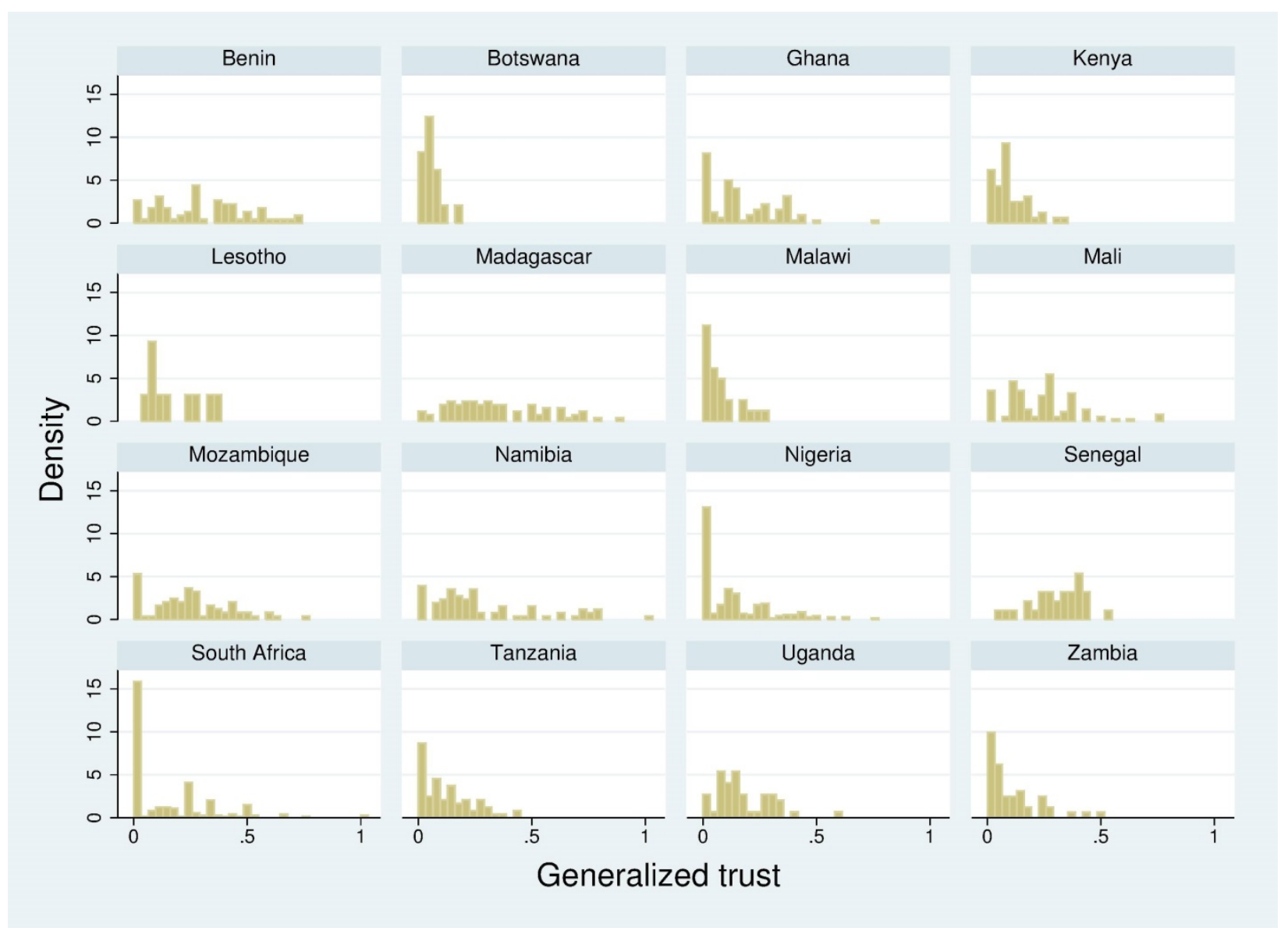

The X-axis represent the percentage of people saying the 'Most people can be trusted" and the Y-axis the number of districts 
Figure 2: Distribution of district-level trust in neighbors by country

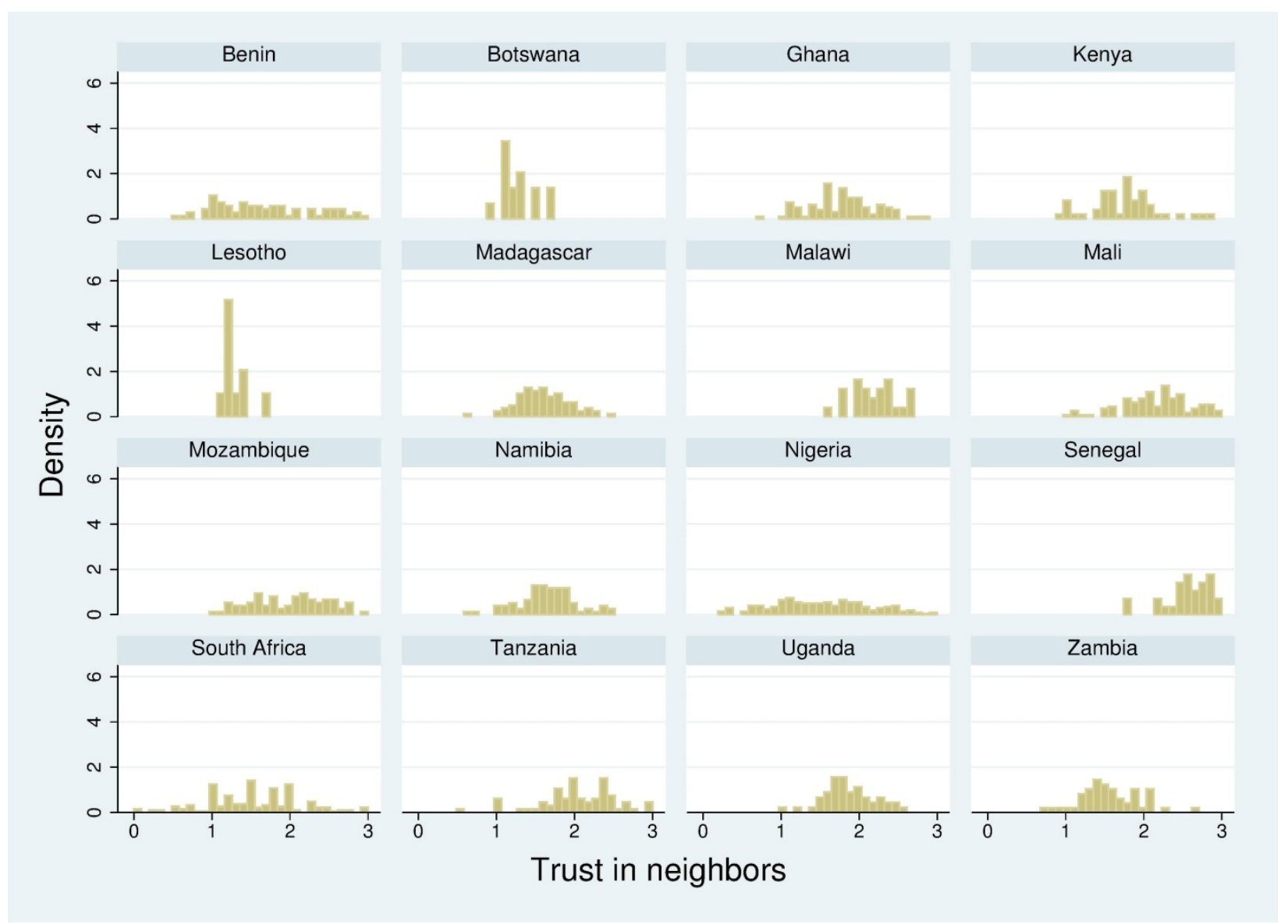

The $\mathrm{X}$-axis represent the average level of localized trust and the $\mathrm{Y}$-axis the number of districts 
Table 6: IV estimation of the effect of trust on health-center quality

\begin{tabular}{|c|c|c|c|c|c|c|c|}
\hline & EXP & MES & DABS & LWA & PFA & ILP & LREP \\
\hline \multirow[t]{2}{*}{ Trust_NEIGH } & $.299 * * *$ & $.284 * * *$ & $.221 * *$ & $.307 * * *$ & $.330 * * *$ & $.301 * * *$ & $.464 * * *$ \\
\hline & $(.0908)$ & $(.1033)$ & $(.0812)$ & (.0919) & $(.0828)$ & $(.1142)$ & $(.0871)$ \\
\hline \multirow[t]{2}{*}{ Constant } & $-2.281 * * *$ & $-1.521 * * *$ & $-1.075^{* * *}$ & $-1.759 * * *$ & $-1.159 * * *$ & $-1.310 * *$ & $-1.978 * * *$ \\
\hline & $(.2746)$ & $(.3222)$ & $(.2967)$ & $(.2947)$ & $(.2654)$ & $(.4388)$ & $(.2973)$ \\
\hline \multicolumn{8}{|l|}{ Exogeneity test } \\
\hline Durbin Chi2(1) & $8.40 * * *$ & $7.21 * * *$ & 2.30 & $7.67 * * *$ & $4.39 * * *$ & $4.24 * *$ & $14.55 * * *$ \\
\hline Wu-Hausman $F(1, N)$ & $8.40 * * *$ & $7.04 * * *$ & 2.24 & $7.50 * * *$ & $4.28 * *$ & $4.13 * *$ & $14.32 * * *$ \\
\hline $\begin{array}{l}\text { Adj. } \mathrm{R}^{2} \\
\text { No. of cases }\end{array}$ & $\begin{array}{c}.281 \\
1010 \\
\end{array}$ & $\begin{array}{l}186 \\
1009 \\
\end{array}$ & $\begin{array}{l}.206 \\
1007 \\
\end{array}$ & $\begin{array}{l}.262 \\
1006 \\
\end{array}$ & $\begin{array}{c}.184 \\
1006 \\
\end{array}$ & $\begin{array}{c}.060 \\
1007 \\
\end{array}$ & $\begin{array}{c}.207 \\
1007 \\
\end{array}$ \\
\hline \multirow[t]{2}{*}{ Trust_GVS } & $.182 *$ & $.360 * *$ & .093 & $.290 * *$ & $.252 * *$ & .107 & $.281 * *$ \\
\hline & $(.3803)$ & $(.4421)$ & $(.3594)$ & $(.3743)$ & $(.3585)$ & $(.5692)$ & $(.3637)$ \\
\hline \multirow[t]{2}{*}{ Constant } & $-1.914 * * *$ & $-1.416^{* * *}$ & $-.753 * *$ & $-1.505 * * *$ & $-.843 * *$ & -.653 & $-1.413 * * *$ \\
\hline & $(.2785)$ & $(.3346)$ & $(.2810)$ & $(.2935)$ & $(.2788)$ & $(.4255)$ & $(.2837)$ \\
\hline \multicolumn{8}{|l|}{ Exogeneity test } \\
\hline Durbin Chi2(1) & 2.29 & $8.04 * * *$ & 0.314 & $4.82 * *$ & $5.22 * *$ & 1.56 & $3.73 * *$ \\
\hline Wu-Hausman $\mathrm{F}(1, \mathrm{~N})$ & 2.29 & $7.86 * * *$ & 0.305 & $4.70 * *$ & $5.09 * *$ & 1.55 & $3.53 * *$ \\
\hline $\begin{array}{l}\text { Adj. } \mathrm{R}^{2} \\
\text { No. of cases }\end{array}$ & $\begin{array}{r}.281 \\
1010 \\
\end{array}$ & $\begin{array}{l}.140 \\
1009 \\
\end{array}$ & $\begin{array}{l}.203 \\
1007 \\
\end{array}$ & $\begin{array}{l}.242 \\
1006 \\
\end{array}$ & $\begin{array}{c}.131 \\
1006 \\
\end{array}$ & $\begin{array}{c}.053 \\
979 \\
\end{array}$ & $\begin{array}{c}.197 \\
1007 \\
\end{array}$ \\
\hline
\end{tabular}

This table shows the results from IV estimations. The dependent variables describe district health-center quality. The standardized coefficients are reported. Standard errors are in parentheses. The district-level controls are median age, economic conditions, the proportion of individuals with formal education, the proportion of individuals living in urban areas, the percentage membership in $\mathrm{CBOs}$ and religious groups, the distribution of health centers and health etinies within walking distanee, and distriet road and reereational facilities. * Signiffeant at $90 \%$, * Signifieant at $95 \%$ and $* * *$ Significant at $99 \%$. 
Table 7: Estimate of the effect of trust on the water-treatment index

\begin{tabular}{|c|c|c|c|c|}
\hline & OLS & OLS & IV & IV \\
\hline Trust_NEIGH & $\begin{array}{l}.030 \\
(.0139)\end{array}$ & & $\begin{array}{l}.080 * * \\
(.0225)\end{array}$ & \\
\hline Trust_GVS & & $\begin{array}{l}.023 \\
(.0359)\end{array}$ & & $\begin{array}{l}.068 \\
(.1092)\end{array}$ \\
\hline Wealth index & $\begin{array}{l}.012 * * * \\
(.0034)\end{array}$ & $\begin{array}{l}.012 * * * \\
(.0033)\end{array}$ & $\begin{array}{l}.014 * * * \\
(.0036)\end{array}$ & $\begin{array}{l}.012 * * * \\
(.0033)\end{array}$ \\
\hline Sex & $\begin{array}{c}-.005 \\
(.0110)\end{array}$ & $\begin{array}{c}-.004 \\
(.0110)\end{array}$ & $\begin{array}{c}-.007 \\
(.0113)\end{array}$ & $\begin{array}{c}-.005 \\
(.0111)\end{array}$ \\
\hline Age & $\begin{array}{l}-.000 * * \\
(.0002)\end{array}$ & $\begin{array}{l}-.000 * * \\
(.0002)\end{array}$ & $\begin{array}{l}-.000 * \\
(.0002)\end{array}$ & $\begin{array}{l}-.000 * * \\
(.0002)\end{array}$ \\
\hline \multicolumn{5}{|l|}{ Education(ref: no school) } \\
\hline Primary school & $\begin{array}{l}.020 * * * \\
(.0054)\end{array}$ & $\begin{array}{l}.020 * * * \\
(.0054)\end{array}$ & $\begin{array}{l}.022 * * * \\
(.0057)\end{array}$ & $\begin{array}{l}.021 * * * \\
(.0055)\end{array}$ \\
\hline Secondary school & $\begin{array}{l}.024 * * \\
(.0073)\end{array}$ & $\begin{array}{l}.023 * * \\
(.0074)\end{array}$ & $\begin{array}{l}.027 * * * \\
(.0079)\end{array}$ & $\begin{array}{l}.024 * * \\
(.0075)\end{array}$ \\
\hline High school & $\begin{array}{l}.037 * * \\
(.0165)\end{array}$ & $\begin{array}{l}.036 * * \\
(.0166)\end{array}$ & $\begin{array}{l}.043 * * \\
(.0170)\end{array}$ & $\begin{array}{l}.042 * * \\
(.0169)\end{array}$ \\
\hline Type of place of residence & $\begin{array}{l}.066^{* * *} \\
(.0166)\end{array}$ & $\begin{array}{l}.067 * * * \\
(.0165)\end{array}$ & $\begin{array}{l}.067 * * * \\
(.0167)\end{array}$ & $\begin{array}{l}.069 * * * \\
(.0162)\end{array}$ \\
\hline Fractionalization & $\begin{array}{c}-.018 \\
(.0239)\end{array}$ & $\begin{array}{c}-.020 \\
(.0244)\end{array}$ & $\begin{array}{c}-.021 \\
(.0245)\end{array}$ & $\begin{array}{c}-.029 \\
(.0276)\end{array}$ \\
\hline Prop urban & $\begin{array}{c}-.013 \\
(.0192)\end{array}$ & $\begin{array}{c}-.016 \\
(.0190)\end{array}$ & $\begin{array}{c}-.008 \\
(.0195)\end{array}$ & $\begin{array}{c}-.015 \\
(.0193)\end{array}$ \\
\hline Prop join other & $\begin{array}{c}.004 \\
(.0190)\end{array}$ & $\begin{array}{c}.004 \\
(.0191)\end{array}$ & $\begin{array}{c}.006 \\
(.0195)\end{array}$ & $\begin{array}{c}.006 \\
(.0196)\end{array}$ \\
\hline Prop meeting & $\begin{array}{c}-.029 \\
(.0182)\end{array}$ & $\begin{array}{c}-.026 \\
(.0172)\end{array}$ & $\begin{array}{l}-.032 * \\
(.0187)\end{array}$ & $\begin{array}{c}-.021 \\
(.0179)\end{array}$ \\
\hline Prop member CBO & $\begin{array}{c}-.007 \\
(.0366)\end{array}$ & $\begin{array}{c}-.009 \\
(.0369)\end{array}$ & $\begin{array}{c}-.007 \\
(.0381)\end{array}$ & $\begin{array}{c}-.015 \\
(.0391)\end{array}$ \\
\hline Recrea facilities & $\begin{array}{c}-.002 \\
(.0154)\end{array}$ & $\begin{array}{c}.000 \\
(.0150)\end{array}$ & $\begin{array}{c}-.001 \\
(.0159)\end{array}$ & $\begin{array}{c}.007 \\
(.0157)\end{array}$ \\
\hline Road & $\begin{array}{c}-.006 \\
(.0188)\end{array}$ & $\begin{array}{c}-.006 \\
(.0192)\end{array}$ & $\begin{array}{c}-.005 \\
(.0193)\end{array}$ & $\begin{array}{c}-.004 \\
(.0205)\end{array}$ \\
\hline Constant & $\begin{array}{c}.017 \\
(.0576)\end{array}$ & $\begin{array}{c}.039 \\
(.0534)\end{array}$ & $\begin{array}{c}-.054 \\
(.0717)\end{array}$ & $\begin{array}{c}-.008 \\
(.0750)\end{array}$ \\
\hline \multicolumn{5}{|l|}{ Exogeneity test } \\
\hline Durbin Chi2(1) & & & $76.75 * * *$ & $50.91 * * *$ \\
\hline Wu-Hausman F(1,N) & & & $76.79 * * *$ & $50.92 * * *$ \\
\hline $\begin{array}{l}\text { Adj. } \mathrm{R}^{2} \\
\text { No. of cases }\end{array}$ & $\begin{array}{l}.505 \\
100573\end{array}$ & $\begin{array}{l}.505 \\
100573\end{array}$ & $\begin{array}{l}.506 \\
99664\end{array}$ & $\begin{array}{c}.505 \\
9966\end{array}$ \\
\hline
\end{tabular}

The standardized coefficients are reported. Standard errors are in parentheses. * Significant at $90 \%$, $* *$ Significant at $95 \%$ and $* * *$ Significant at $99 \%$. 
Table 8: Estimate of the effect of trust on access to protected wells

\begin{tabular}{|c|c|c|c|c|}
\hline & OLS & IV & OLS & IV \\
\hline Trust_NEIGH & $\begin{array}{c}.060 \\
(.0238)\end{array}$ & $\begin{array}{l}.330 * * * \\
(.0497)\end{array}$ & & \\
\hline Trust_GVS & & & $\begin{array}{c}-.014 \\
(.0640)\end{array}$ & $\begin{array}{l}.179 * \\
(.1844)\end{array}$ \\
\hline Fractionalization & $\begin{array}{c}.025 \\
(.0421)\end{array}$ & $\begin{array}{c}.031 \\
(.0438)\end{array}$ & $\begin{array}{c}.025 \\
(.0423)\end{array}$ & $\begin{array}{c}.013 \\
(.0442)\end{array}$ \\
\hline Median age & $\begin{array}{c}-.005 \\
(.0033)\end{array}$ & $\begin{array}{c}-.003 \\
(.0034)\end{array}$ & $\begin{array}{c}-.005 \\
(.0033)\end{array}$ & $\begin{array}{c}-.004 \\
(.0034)\end{array}$ \\
\hline Wealth Second quartile & $\begin{array}{c}-.042 \\
(.0269)\end{array}$ & $\begin{array}{c}-.011 \\
(.0288)\end{array}$ & $\begin{array}{l}-.049 * \\
(.0267)\end{array}$ & $\begin{array}{c}-.041 \\
(.0275)\end{array}$ \\
\hline Third quartile & $\begin{array}{c}-.022 \\
(.0293)\end{array}$ & $\begin{array}{c}.027 \\
(.0323)\end{array}$ & $\begin{array}{c}-.032 \\
(.0287)\end{array}$ & $\begin{array}{c}-.021 \\
(.0298)\end{array}$ \\
\hline Fourth quartile & $\begin{array}{l}-.064 * * \\
(.0314)\end{array}$ & $\begin{array}{c}-.026 \\
(.0338)\end{array}$ & $\begin{array}{l}-.072 * * \\
(.0310)\end{array}$ & $\begin{array}{l}-.065 * * \\
(.0319)\end{array}$ \\
\hline Prop urban & $\begin{array}{l}-.086^{* *} \\
(.0299)\end{array}$ & $\begin{array}{l}-.059 * \\
(.0318)\end{array}$ & $\begin{array}{l}-.092 * * \\
(.0298)\end{array}$ & $\begin{array}{l}-.084 * * \\
(.0308)\end{array}$ \\
\hline Prop join other & $\begin{array}{c}.040 \\
(.0334)\end{array}$ & $\begin{array}{c}.049 \\
(.0353)\end{array}$ & $\begin{array}{c}.039 \\
(.0335)\end{array}$ & $(.0349)$ \\
\hline Prop meeting & $\begin{array}{c}-.014 \\
(.0272)\end{array}$ & $\begin{array}{c}-.035 \\
(.0288)\end{array}$ & $\begin{array}{l}-.010 \\
(.0272)\end{array}$ & $\begin{array}{c}-.014 \\
(.0280)\end{array}$ \\
\hline Prop member $\mathrm{CBO}$ & $\begin{array}{c}-.002 \\
(.0594)\end{array}$ & $\begin{array}{c}-.033 \\
(.0626)\end{array}$ & $\begin{array}{c}.003 \\
(.0595)\end{array}$ & $\begin{array}{c}-.025 \\
(.0623)\end{array}$ \\
\hline Prop raising issue & $\begin{array}{c}-.061 \\
(.0996)\end{array}$ & $\begin{array}{c}-.011 \\
(.1050)\end{array}$ & $\begin{array}{c}-.073 \\
(.0996)\end{array}$ & $\begin{array}{c}-.063 \\
(.1033)\end{array}$ \\
\hline Recrea facilities & $\begin{array}{c}-.014 \\
(.0247)\end{array}$ & $\begin{array}{c}-.012 \\
(.0258)\end{array}$ & $\begin{array}{c}-.016 \\
(.0249)\end{array}$ & $\begin{array}{c}-.007 \\
(.0262)\end{array}$ \\
\hline Road & $\begin{array}{c}.010 \\
(.0283)\end{array}$ & $\begin{array}{l}.023 \\
(.0298)\end{array}$ & $\begin{array}{c}.007 \\
(.0283)\end{array}$ & $\begin{array}{c}.020 \\
(.0299)\end{array}$ \\
\hline Prop memb religious & $\begin{array}{c}.009 \\
(.0315)\end{array}$ & $\begin{array}{c}.026 \\
(.0331)\end{array}$ & $\begin{array}{c}.006 \\
(.0315)\end{array}$ & $\begin{array}{c}.015 \\
(.0327)\end{array}$ \\
\hline Constant & $\begin{array}{l}.678 * * * \\
(.1933)\end{array}$ & $\begin{array}{l}.241 \\
(.2280)\end{array}$ & $\begin{array}{l}.781 * * * \\
(.1853)\end{array}$ & $\begin{array}{l}.655 * * \\
(.1991)\end{array}$ \\
\hline \multicolumn{5}{|l|}{ Exogeneity test } \\
\hline Durbin Chi2(1) & & $16.52 * * *$ & & $4.91 * *$ \\
\hline Wu-Hausman $F(1, N)$ & & $16.25 * * *$ & & $4.74 * *$ \\
\hline $\begin{array}{l}\text { Adj. } \mathrm{R}^{2} \\
\text { No. of cases }\end{array}$ & $\begin{array}{c}.446 \\
609 \\
\end{array}$ & $\begin{array}{r}.407 \\
598 \\
\end{array}$ & $\begin{array}{r}.444 \\
609 \\
\end{array}$ & $\begin{array}{r}.417 \\
598 \\
\end{array}$ \\
\hline
\end{tabular}

The standardized coefficients are reported. Standard errors are in parentheses. * Significant at $90 \%$, ** Significant at $95 \%$ and $* * *$ Significant at $99 \%$. 


\begin{tabular}{|c|c|c|c|c|c|c|c|}
\hline & EXP & MES & DABS & LWA & PFA & ILP & LREP \\
\hline Trust_GVS & $\begin{array}{l}.327 \\
(.418)\end{array}$ & $\begin{array}{l}1.066^{* *} \\
(.443)\end{array}$ & $\begin{array}{l}.111 \\
(.402)\end{array}$ & $\begin{array}{l}.780 * * \\
(.388)\end{array}$ & $\begin{array}{l}.847 * * \\
(.380)\end{array}$ & $\begin{array}{l}.427 \\
(.683)\end{array}$ & $\begin{array}{l}.866^{* *} \\
(.385)\end{array}$ \\
\hline Slave exports & $\begin{array}{l}-.099 * * * \\
(.027)\end{array}$ & $\begin{array}{l}-.076^{* *} \\
(.030)\end{array}$ & $\begin{array}{l}-.093^{* * *} \\
(.024)\end{array}$ & $\begin{array}{l}-.110^{* * * *} \\
(.028)\end{array}$ & $\begin{array}{l}-.104 * * * \\
(.025)\end{array}$ & $\begin{array}{l}-.042 \\
(.046)\end{array}$ & $\begin{array}{l}-.117^{* * *} \\
(.026)\end{array}$ \\
\hline Total missions per land area & $\begin{array}{l}66.01 \\
(68.45)\end{array}$ & $\begin{array}{l}125.90 \\
(87.84)\end{array}$ & $\begin{array}{l}54.16 \\
(78.25)\end{array}$ & $\begin{array}{l}86.01 \\
(78.92)\end{array}$ & $\begin{array}{l}67.96 \\
(79.21)\end{array}$ & $\begin{array}{l}-246.27 \\
(161.61)\end{array}$ & $\begin{array}{l}97.77 \\
(71.30)\end{array}$ \\
\hline Indicator city in 1400 & $\begin{array}{l}.067 \\
(.078)\end{array}$ & $\begin{array}{l}-.043 \\
(.082)\end{array}$ & $\begin{array}{l}.034 \\
(.065)\end{array}$ & $\begin{array}{l}.135^{*} \\
(.080)\end{array}$ & $\begin{array}{l}.060 \\
(.074)\end{array}$ & $\begin{array}{l}.046 \\
(.114)\end{array}$ & $\begin{array}{l}.035 \\
(.071)\end{array}$ \\
\hline Colonial railway network & $\begin{array}{l}-.123 * * \\
(.048)\end{array}$ & $\begin{array}{l}-.192 * * * \\
(.057)\end{array}$ & $\begin{array}{l}-.025 \\
(.045)\end{array}$ & $\begin{array}{l}-.173 * * \\
(.053)\end{array}$ & $\begin{array}{l}-.040 \\
(.050)\end{array}$ & $\begin{array}{l}.048 \\
(.082)\end{array}$ & $\begin{array}{l}-.054 \\
(.048)\end{array}$ \\
\hline Malaria ecology & $\begin{array}{l}-.002 \\
(.004)\end{array}$ & $\begin{array}{l}.005 \\
(.005)\end{array}$ & $\begin{array}{l}.006 \\
(.005)\end{array}$ & $\begin{array}{l}.011^{* *} \\
(.005)\end{array}$ & $\begin{array}{l}.014 * * \\
(.005)\end{array}$ & $\begin{array}{l}.007 \\
(.007)\end{array}$ & $\begin{array}{l}.008^{* *} \\
(.004)\end{array}$ \\
\hline Log pop density & $\begin{array}{l}-.025 \\
(.024)\end{array}$ & $\begin{array}{l}-.066^{* *} \\
(.024)\end{array}$ & $\begin{array}{l}-.001 \\
(.026)\end{array}$ & $\begin{array}{l}-.020 \\
(.022)\end{array}$ & $\begin{array}{l}.012 \\
(.028)\end{array}$ & $\begin{array}{l}-.001 \\
(.038)\end{array}$ & $\begin{array}{l}.002 \\
(.024)\end{array}$ \\
\hline Constant & $\begin{array}{l}-1.421^{* * *} \\
(.317)\end{array}$ & $\begin{array}{l}-.928^{* *} \\
(.378)\end{array}$ & $\begin{array}{l}-.648^{*} \\
(.339)\end{array}$ & $\begin{array}{l}-1.319^{* * *} \\
(.340)\end{array}$ & $\begin{array}{l}-1.047^{* *} \\
(.352)\end{array}$ & $\begin{array}{l}-.844 \\
(.523)\end{array}$ & $\begin{array}{l}-1.328^{* * *} \\
(.326)\end{array}$ \\
\hline $\begin{array}{l}\text { Adj. } R^{2} \\
\text { No. of cases }\end{array}$ & $\begin{array}{l}.272 \\
895\end{array}$ & $\begin{array}{l}.171 \\
894\end{array}$ & $\begin{array}{l}.212 \\
892\end{array}$ & $\begin{array}{l}.283 \\
891\end{array}$ & $\begin{array}{l}.160 \\
891\end{array}$ & $\begin{array}{l}.041 \\
892\end{array}$ & $\begin{array}{l}.221 \\
892\end{array}$ \\
\hline
\end{tabular}

This table shows the results from IV estimations. The regressions include country fixed effects. The dependent variables refer to district health-center quality. Standard errors are in parentheses. The district-level controls are median age, economic conditions, the proportion of individuals with formal education, the proportion of individuals living in urban areas, the percentage who paid bribes in the districts, the percentage membership in $\mathrm{CBOs}$ and religious groups, the distribution of schools and health clinics within walking distance, and district roads and recreational facilities.

* Significant at $90 \%, * *$ Significant at $95 \%$ and *** Significant at $99 \%$. 
Table 10: IV estimation of the effect of trust in neighbors on health-center quality with historical controls

\begin{tabular}{|c|c|c|c|c|c|c|c|}
\hline & EXP & MES & DABS & LWA & PFA & ILP & LREP \\
\hline Trust_NEIGH & $\begin{array}{l}.328^{* *} \\
(.115)\end{array}$ & $\begin{array}{l}.335^{* *} \\
(.126)\end{array}$ & $\begin{array}{l}.150 \\
(.101)\end{array}$ & $\begin{array}{l}.296^{* *} \\
(.114)\end{array}$ & $\begin{array}{l}.372^{* * *} \\
(.103)\end{array}$ & $\begin{array}{l}.386^{* *} \\
(.152)\end{array}$ & $\begin{array}{l}.562^{* * * *} \\
(.104)\end{array}$ \\
\hline Slave exports & $\begin{array}{l}-.070^{* *} \\
(.031)\end{array}$ & $\begin{array}{l}-.058^{*} \\
(.033)\end{array}$ & $\begin{array}{l}-.079 * * \\
(.026)\end{array}$ & $\begin{array}{l}-.091 * * \\
(.029)\end{array}$ & $\begin{array}{l}-.076^{* *} \\
(.027)\end{array}$ & $\begin{array}{l}-.008 \\
(.050)\end{array}$ & $\begin{array}{l}-.070^{* *} \\
(.029)\end{array}$ \\
\hline Total mission per land area & $\begin{array}{l}92.00 \\
(71.24)\end{array}$ & $\begin{array}{l}137.27 \\
(89.29)\end{array}$ & $\begin{array}{l}67.00 \\
(77.71)\end{array}$ & $\begin{array}{l}98.51 \\
(77.51)\end{array}$ & $\begin{array}{l}87.30 \\
(79.57)\end{array}$ & $\begin{array}{l}-216.32 \\
(167.02)\end{array}$ & $\begin{array}{l}136.05^{*} \\
(72.73)\end{array}$ \\
\hline Indicator city in 1400 & $\begin{array}{l}-.032 \\
(.083)\end{array}$ & $\begin{array}{l}-.163 * \\
(.087)\end{array}$ & $\begin{array}{l}-.010 \\
(.070)\end{array}$ & $\begin{array}{l}.030 \\
(.082)\end{array}$ & $\begin{array}{l}-.064 \\
(.076)\end{array}$ & $\begin{array}{l}-.072 \\
(.113)\end{array}$ & $\begin{array}{l}-.144 * \\
(.075)\end{array}$ \\
\hline Colonial railway network & $\begin{array}{l}-.097 * \\
(.052)\end{array}$ & $\begin{array}{l}-.164^{* *} \\
(.058)\end{array}$ & $\begin{array}{l}-.014 \\
(.046)\end{array}$ & $\begin{array}{l}-.150^{* *} \\
(.052)\end{array}$ & $\begin{array}{l}-.011 \\
(.050)\end{array}$ & $\begin{array}{l}.078 \\
(.082)\end{array}$ & $\begin{array}{l}-.011 \\
(.052)\end{array}$ \\
\hline Malaria ecology & $\begin{array}{l}.001 \\
(.005)\end{array}$ & $\begin{array}{l}.007 \\
(.006)\end{array}$ & $\begin{array}{l}.008 \\
(.005)\end{array}$ & $\begin{array}{l}.013^{* *} \\
(.005)\end{array}$ & $\begin{array}{l}.016^{* *} \\
(.005)\end{array}$ & $\begin{array}{l}.009 \\
(.007)\end{array}$ & $\begin{array}{l}.012 * * \\
(.004)\end{array}$ \\
\hline Log pop density & $\begin{array}{l}-.022 \\
(.025)\end{array}$ & $\begin{array}{l}-.065^{* *} \\
(.023)\end{array}$ & $\begin{array}{l}-.000 \\
(.026)\end{array}$ & $\begin{array}{l}-.019 \\
(.022)\end{array}$ & $\begin{array}{l}.014 \\
(.028)\end{array}$ & $\begin{array}{l}.002 \\
(.038)\end{array}$ & $\begin{array}{l}.005 \\
(.025)\end{array}$ \\
\hline Constant & $\begin{array}{l}-1.956^{* * * *} \\
(.339)\end{array}$ & $\begin{array}{l}-1.143^{* *} \\
(.413)\end{array}$ & $\begin{array}{l}-.915^{* *} \\
(.370)\end{array}$ & $\begin{array}{l}-1.576^{* * *} \\
(.365)\end{array}$ & $\begin{array}{l}-1.439 * * * \\
(.368)\end{array}$ & $\begin{array}{l}-1.463^{* *} \\
(.527)\end{array}$ & $\begin{array}{l}-2.113 * * * \\
(.367)\end{array}$ \\
\hline $\begin{array}{l}\text { Adj. } R^{2} \\
\text { No. of cases }\end{array}$ & $\begin{array}{l}.260 \\
895\end{array}$ & $\begin{array}{l}.193 \\
894\end{array}$ & $\begin{array}{l}.220 \\
892\end{array}$ & $\begin{array}{l}.293 \\
891\end{array}$ & $\begin{array}{l}.212 \\
891\end{array}$ & $\begin{array}{l}.050 \\
892\end{array}$ & $\begin{array}{l}.215 \\
892\end{array}$ \\
\hline
\end{tabular}

This table shows the results from IV estimations. The regressions include country fixed effects. The dependent variables refer to district health-center quality. Standard errors are in parentheses. The district-level controls are median age, economic conditions, the proportion of individuals with formal education, the proportion of individuals living in urban areas, the percentage who paid bribes in the districts, the percentage membership in CBOs and religious groups, the distribution of schools and health clinics within walking distance, and district roads and recreational facilities.

* Significant at $90 \%, * *$ Significant at $95 \%$ and $* * *$ Significant at $99 \%$. 
Figure 3: The historical territories of ethnic groups

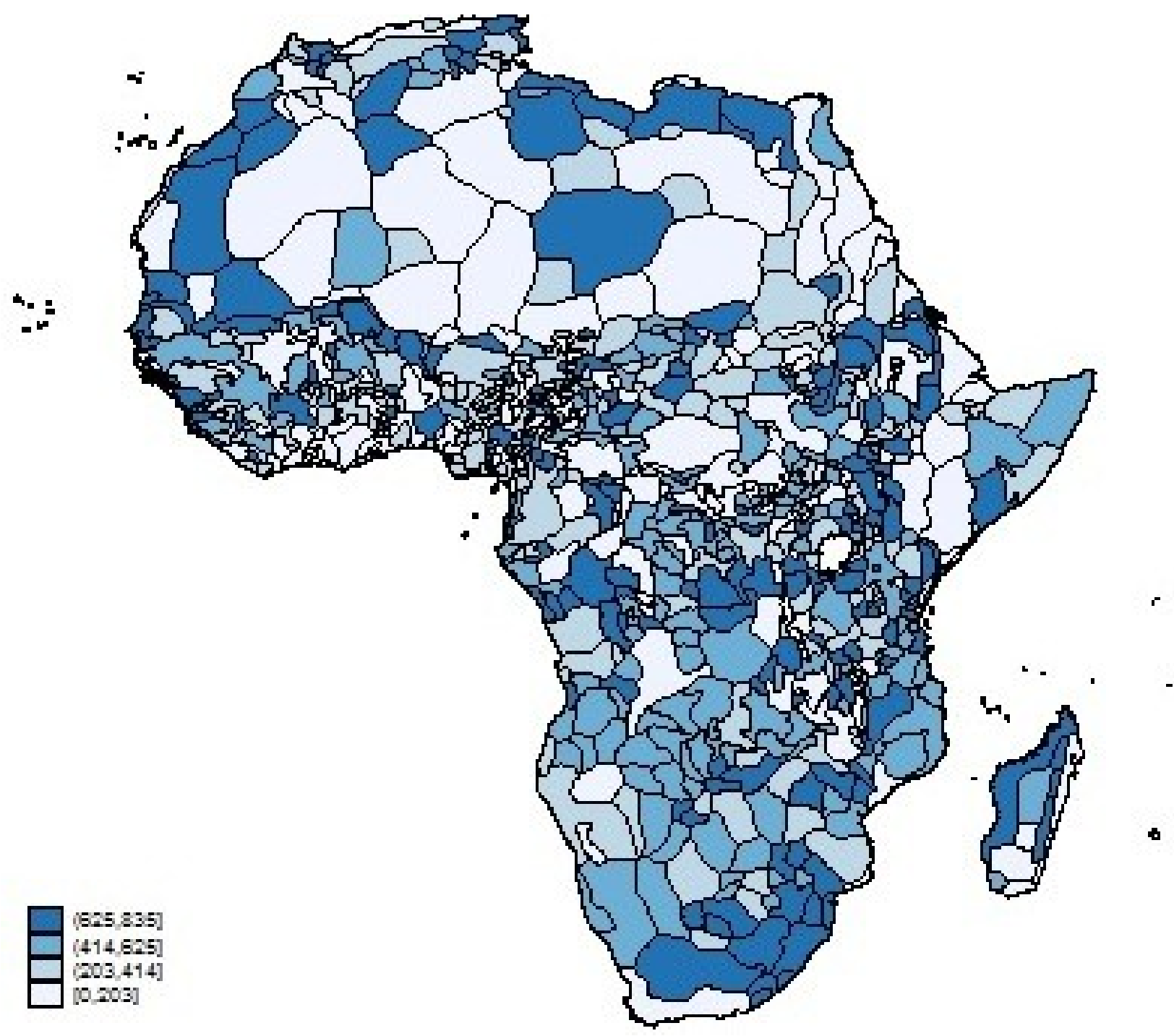

The colors represent the density of population. Darker colors indicate higher density 